OPEN ACCESS

Edited by:

Luis Graca,

University of Lisbon, Portugal

Reviewed by:

Paulo Vieira,

Institut Pasteur de Paris, France

Martin Johannes Hoogduijn,

Erasmus Medical Center, Netherlands

*Correspondence: Karen Bieback karen.bieback@medma. uni-heidelberg.de

Specialty section: This article was submitted to Immunological Tolerance, a section of the journal

Frontiers in Immunology

Received: 11 August 2015 Accepted: 19 October 2015 Published: 03 November 2015

Citation:

Mattar P and Bieback K (2015) Comparing the immunomodulatory properties of bone marrow, adipose tissue, and birth-associated tissue mesenchymal stromal cells.

Front. Immunol. 6:560. doi: 10.3389/fimmu.2015.00560

\section{Comparing the immunomodulatory properties of bone marrow, adipose tissue, and birth-associated tissue mesenchymal stromal cells}

\author{
Philipp Mattar ${ }^{1,2}$ and Karen Bieback ${ }^{1,2 *}$ \\ 'Stem Cell Laboratory, Medical Faculty Mannheim, Institute of Transfusion Medicine and Immunology, Heidelberg University, \\ Heidelberg, Germany, ${ }^{2}$ German Red Cross Blood Service Baden-Württemberg - Hessen, Mannheim, Germany
}

Mesenchymal stromal cells (MSC) have gained immense attraction in regenerative medicine, tissue engineering, and immunotherapy. This is based on their differentiation potential and the supply of pro-regenerative and immunomodulatory signals. MSC can be isolated from a multitude of tissue sources, but mainly bone marrow, adipose tissue, and birth-associated tissues (e.g., umbilical cord, cord blood, placenta) appear to be relevant for clinical translation in immune-mediated disorders. However, only a few studies directly compared the immunomodulatory potency of MSC from different tissue sources. This review compiles the current literature regarding the similarities and differences between these three sources for MSCs with a special focus on their immunomodulatory effects on T-lymphocyte subsets and monocytes, macrophages, and dendritic cells.

Keywords: mesenchymal stromal cells, immunomodulation, $\mathrm{T}$ cells, regulatory $\mathrm{T}$ cells, macrophages, bone marrow, adipose tissue, umbilical cord

\section{INTRODUCTION}

Human mesenchymal stromal cells (MSC) have been an attractive target for translational research in a wide range of therapeutic applications due to their paracrine effects, multi-lineage differentiation potential and, most importantly, their immunomodulatory properties $(1,2)$. Bone marrow was the first established source of these cells (3). Since then it has been the primary and therefore most investigated population. Over the last few years, several other sources for MSC have been identified $(4,5)$. In our view, after bone marrow-derived MSCs (hereafter referred to as BM-MSC), adipose tissue-derived MSCs (hereafter referred to as AT-MSC), and birth-associated MSCs (from umbilical cord blood, cord tissue, and placenta, referred to as UCB-MSC, UC-MSC, and PL-MSC, respectively) (6) are most commonly used as sources of human MSCs in a clinical setting. These may be favored due to different advantages: greater yields of MSCs than BM, higher proliferative potential, and no ethical restrictions (5-10). It has to be noted that birth-associated tissue is not one single source of MSCs but rather a comprising name for several subpopulations, namely amnion, umbilical cord, cord blood, and placenta. Most of them can be categorized further into even more subpopulations.

\footnotetext{
Abbreviations: AT, adipose tissue; BM, bone marrow; CTL, cytotoxic T lymphocytes; DC, dendritic cells; MLR, mixed lymphocyte reaction; MSC, mesenchymal stromal cells; PBMC, peripheral blood mononuclear cells; PL, placenta; Treg, regulatory T cells; UC, umbilical cord; UCB, umbilical cord blood; WJ, Wharton’s jelly.
} 
Mesenchymal stromal cells from different sources are similar in a range of phenotypic and functional features (5). There are, however, subtle differences, which may result from the microenvironmental niche, the local function (stromal support of hematopoiesis in the BM and immune homeostasis by AT), and the ontogenetic age (birth-associated versus adult) $(5,7,11)$ or induced by the isolation and culture procedure. CD106 is one example, as it is significantly reduced on AT-MSCs compared to other MSCs $(5,12,13)$. CD34, on the other hand, appears on AT-MSCs in situ and early in culture but on no other MSCs (14, 15). Regarding function, we and others reported for example significantly reduced adipogenic differentiation capacity of UCBMSC (16). Regarding the stromal supportive capacity, a recent study indicates that only BM-MSC (not MSC from white adipose tissue, umbilical cord, and skin) are capable to form a functional hematopoietic niche (17).

Immunomodulatory functions have been reported for all types of MSC tested. Strikingly, analyses directly comparing these populations with their immunomodulatory effects are limited. As many scientific groups just use one single source for MSCs in their experiments - indeed beneficial for the reproducibility of their own data - it renders it hard to compare the results to those of other scientists and to draw conclusions about their clinical efficacy. To assess immunomodulation, most groups utilize a mixed lymphocyte reaction (MLR) assay or an assay measuring $\mathrm{T}$ cell proliferation induced by mitogens or CD3/CD28 stimulation. Fewer groups address distinct effects on T cell subsets (Th1, Th2, Th17, and regulatory $\mathrm{T}$ cells) and antigen-presenting cells (APCs) [reviewed in Ref. $(2,18,19)$ ]. Although the vast majority of studies confirm MSCs to inhibit the immune response, recent data identified allogeneic MSCs to be immunogenic and immune-rejected under appropriate conditions (20-22). There is a large diversity in soluble factors to mediate the effects of MSCs, thus it remains to be clarified whether MSC origin and culture conditions use different molecular mechanisms to exert their effects $(2,23)$. Some interesting data suggest intrinsic differences in expression of immune-related signature genes, mi- and tRNA species $(24,25)$. However, a summary of these is beyond the scope of this review. Here, we focused on studies, which directly compared two or more MSC tissue sources addressing MSC effects on T cell subpopulations or APCs, such as monocytes, macrophages, or dendritic cells (DCs) (summarized in Table 1).

\section{EFFECTS ON T CELLS}

\section{Effects on Naïve CD4 ${ }^{+}$T Cells}

The exerted effects on naïve $\mathrm{CD} 4^{+} \mathrm{T}$ cells are of a suppressing and polarizing nature, meaning MSCs inhibit the proliferation and activation of naïve $\mathrm{CD} 4^{+} \mathrm{T}$ helper cells (Th cells). They are able to influence the differentiation of Th0 cells into Th1, Th2, Th17, or regulatory T cells (Tregs) $(36,41,42)$. MSCs seem to hamper T cell proliferation by arresting T cells in the G0/G1 phase of the cell cycle $(12,43)$, thus reducing the total number of T cells undergoing activation. MSCs exert their immunomodulatory functions through numerous molecules. Although trans-well experiments show an inhibiting function of MSCs, most studies confirm a more pronounced effect without trans-wells, highlighting the importance of cell-cell contact in mediating immunomodulatory functions. Prostaglandin E2 (PGE2) seems to play an important role in suppressing the immune response (33). Just recently, evidence arose that MSC-derived microvesicles contain a variety of immunomodulatory factors, including miRNA and tRNA species $(25,44)$. Di Nicola et al. proposed transforming growth factor (TGF)- $\beta$ and hepatocyte growth factor (HGF) as important mediators, as blockage of both significantly reduced the suppressive effect of MSCs (45). Another group identified indoleamine 2,3-dioxygenase (IDO) to be involved (46). IDO catalyzes the conversion of tryptophan, an essential molecule in the activation of T cells, to kynurenine and has been identified as a key pathway for inhibiting $\mathrm{T}$ cell response. Additionally, Human Leukocyte Antigen-G5 (HLA-G5) was found to be required to suppress T cell function and to induce Tregs $(32,47)$.

\section{Comparison}

Comparative studies have produced conflicting results. Puissant et al. report similar inhibition of T cell proliferation, both induced in MLR or mitogens, in presence of BM- or AT-MSCs (35). In both settings suppression was induced by soluble mediators. In contrast, whereas Ribeiro et al. (36) found AT-MSCs (compared to BM-MSCs and UC-MSCs) to have the strongest suppressive effect on the activation and acquisition of lymphoblast characteristics on T cells, Xishan et al. (12) determined BM-MSCs to have a superior immunosuppressive effect over AT-MSCs. In a study comparing MSCs from bone marrow, adipose tissue and Wharton's jelly, AT-MSCs showed the strongest effect on downregulating the activation marker CD38 on T cells, followed by UC-MSCs, whereas BM-MSCs had the weakest effect (33). The authors showed AT-MSCs to be the most potent population in inhibiting allogeneic-induced $\mathrm{T}$ cell proliferation (33). Interestingly, different levels of the enzyme cyclooxygenase-1 (COX1), which is essential in PGE2 production, were observed, with highest levels of COX1 in AT-MSC (33). Conflicting data, however, was presented by Li et al., who determined MSCs from Wharton's jelly to possess the strongest inhibitory effect on T cell proliferation compared to AT-MSCs, BM-MSCs, and PL-MSCs (30). Similar inhibitory effects on T cell proliferation, activation, and cytokine secretion are reported by Luan et al. comparing PL- and BM-MSC (31). They identified programed death-ligand 1 (PD-L1, CD274, or B7-H1) and $\mathrm{B} 7 \mathrm{H} 4$ as negative regulators.

\section{Effects on CD4 ${ }^{+}$Th1 Cells}

A large number of studies have been performed to explore the effects of MSCs on Th1 cells, considered to be the main effector cells of proinflammatory cell-mediated immunity and organspecific autoimmune disorders $(23,48,49)$. The results obtained from these studies usually imply an inhibiting effect on Th1 cells $(12,41,48-50)$. However, there are conditions in which MSCs seem to promote Th1 cells and inhibit the differentiation of Th2 cells (49). Cho et al. described AT-MSCs to reduce Th2-associated cytokines (interleukin IL-4, IL-5) and increase Th1-derived interferon (IFN)- $\gamma$ and IL-2 in a model of eosinophilic nasal polyps (51). These data are corroborated by other studies, confirming the Th2-inhibiting function of MSCs in Th2-dominated 
TABLE 1 | Studies directly comparing different sources of MSCs, reporting differences in immunomodulatory capacities.

\begin{tabular}{|c|c|c|c|}
\hline Reference & Populations compared & Parameters & Outcome \\
\hline Bárcia et al. (26) & $\mathrm{BM}, \cup \mathrm{C}$ & $\begin{array}{l}\text { Immunomod } \\
\text { Immunogenicity }\end{array}$ & $\begin{array}{l}U C>B M \\
U C<B M\end{array}$ \\
\hline Barlow et al. (9) & $\mathrm{BM}, \mathrm{PL}$ & $\begin{array}{l}\text { Proliferation } \\
\text { Immunogenicity }\end{array}$ & $\begin{array}{l}\mathrm{PL}>\mathrm{BM} \\
\mathrm{BM}=\mathrm{PL}\end{array}$ \\
\hline Castro-Manrreza et al. (27) & $\mathrm{BM}, \mathrm{UCB}, \mathrm{PL}$ & Immunomod ${ }^{b}$ & $\mathrm{BM}=\mathrm{UCB}>\mathrm{PL}$ \\
\hline Hass et al. (7) & $\mathrm{BM}, \mathrm{AT}, \mathrm{UC}$ & $\begin{array}{l}\text { Proliferation } \\
\text { Senescence }\end{array}$ & $\begin{array}{l}U C>A T>B M \\
U C<A T<B M\end{array}$ \\
\hline Ivanova-Todorova et al. (28) & $\mathrm{BM}, \mathrm{AT}$ & Immunomod $^{c}$ & $\mathrm{AT}>\mathrm{BM}$ \\
\hline Jin et al. (29) & BM, AT, UCB & $\begin{array}{l}\text { Proliferation } \\
\text { Immunomod }^{d} \\
\text { Senescence }\end{array}$ & $\begin{array}{l}\mathrm{UCB}>A T=B M \\
\mathrm{UCB}>A T=B M \\
\mathrm{UCB}<A T=B M\end{array}$ \\
\hline Kern et al. (5) & $\mathrm{BM}, \mathrm{AT}, \mathrm{UCB}$ & $\begin{array}{l}\text { Proliferation } \\
\text { Isolation success rate } \\
\text { Colony frequency }\end{array}$ & $\begin{array}{l}U C B>A T>B M \\
B M=A T>U C B \\
A T>B M>U C B\end{array}$ \\
\hline Li et al. (30) & BM, AT, UC, PL & $\begin{array}{l}\text { Proliferation } \\
\text { Immunomod }^{\text {Imm }}\end{array}$ & $\begin{array}{l}\mathrm{WJ}>\mathrm{AT}>\mathrm{PL}>\mathrm{BM} \\
\mathrm{WJ}>\mathrm{PL}>\mathrm{AT}>\mathrm{BM}\end{array}$ \\
\hline Luan et al. (31) & $\mathrm{BM}, \mathrm{PL}$ & Immunomod $^{f}$ & $B M=P L$ \\
\hline Montespan et al. (32) & $\mathrm{BM}, \mathrm{AT}$ & Immunomodg & $A T>B M$ \\
\hline Najar et al. $(33,34)$ & $\mathrm{BM}, \mathrm{AT}, \mathrm{UC}$ & Immunomod $^{\text {h }}$ & $\mathrm{AT}>\mathrm{BM}=\mathrm{UC}$ \\
\hline Prasanna et al. (22) & BM, WJ & $\begin{array}{l}\text { Immunogenicity } \\
\text { Immunomodi }\end{array}$ & $\begin{array}{l}B M=W J \\
W J \neq B M\end{array}$ \\
\hline Puissant et al. (35) & $\mathrm{BM}, \mathrm{AT}$ & $\begin{array}{l}\text { Immunogenicity } \\
\text { Immunomodi }\end{array}$ & $\begin{array}{l}\mathrm{BM}=\mathrm{AT} \\
\mathrm{BM}=\mathrm{AT}\end{array}$ \\
\hline Ribeiro et al. (36) & $\mathrm{BM}, \mathrm{AT}, \mathrm{UC}$ & $\begin{array}{l}\text { T/NK cell inhibition } \\
\text { B cell inhibition }\end{array}$ & $\begin{array}{l}\mathrm{AT}>\mathrm{BM}=\mathrm{UC} \\
\mathrm{BM}=\mathrm{AT} \text { (UC none) }\end{array}$ \\
\hline Roemeling-van Rhijn et al. $(37,38)$ & $\mathrm{BM}, \mathrm{AT}$ & $\begin{array}{l}\text { Immunomodk } \\
\text { Immunomod' }\end{array}$ & $\begin{array}{l}\mathrm{BM}=\mathrm{AT} \\
\mathrm{AT}<\mathrm{BM}\end{array}$ \\
\hline Stubbendorf et al. (39) & UCB, WJ, PL, UCL & $\begin{array}{l}\text { Proliferation } \\
\text { Immunomod }^{\mathrm{m}} \\
\text { Immunogenicity }\end{array}$ & $\begin{array}{l}U C L>U C B>W J=P L \\
U C L>U C B=W J=P L \\
U C L \leq P L \leq W J=U C B\end{array}$ \\
\hline Xishan et al. (12) & $\mathrm{BM}, \mathrm{AT}$ & $\begin{array}{l}\text { Proliferation } \\
\text { Immunomod }^{\text {nm }}\end{array}$ & $\begin{array}{l}\mathrm{AT}>\mathrm{BM} \\
\mathrm{BM}>\mathrm{AT}\end{array}$ \\
\hline Yoo et al. (40) & $\mathrm{BM}, \mathrm{AT}, \mathrm{UCB}, \mathrm{WJ}$ & $\begin{array}{l}\text { Immunomod } \\
\text { Cytokines }^{\circ}\end{array}$ & $\begin{array}{l}\mathrm{BM}=\mathrm{AT}=\mathrm{UCB}=\mathrm{WJ} \\
\text { Only } \cup \mathrm{CB} \text { and } \mathrm{WJ}\end{array}$ \\
\hline
\end{tabular}

${ }^{a} M S C s+P B M C s / T$ cells. MLR assay to assess lymphocyte proliferation and immunogenicity. Flow cytometry to measure Treg induction. Comparative gene expression analysis. ${ }^{b} \mathrm{MSCS}+T$ cells ( \pm transwell). Proliferation assay for $C D 4^{+}$and $C D 8^{+} T$ cells. Flow cytometry to assess $T$ cell activation and CTLA-4 and PD- $L 1$ expression. Multiplex assay to measure IFN- $\gamma$, TNF- $\alpha, I L-10$, and IL-4.

cMSCs + Monocytes. Flow cytometry to assess CD14, CD80, CD83, CD86, and HLA-DR. ELISA to measure IL-10 and IL-18. Proteome profile assay for 36 cytokines (e.g., CCL-3 and CCL-4).

${ }^{d}$ MSCS + LPS stimulated rat macrophages. ELISA to assess IL-1 $\alpha, I L-6$, and IL-8 and Ang- 1 .

eMSCs + T cells. T cell proliferation was assessed.

${ }^{7} M S C s+T$ cells. T cell proliferation assay. ELISA to assess IFN- $\gamma$ and IL-10, or TNF- $\alpha$.

${ }^{9} M S C s+P B M C s$. Flow cytometry analysis for HLA-G. MLR assay to assess immunosuppression.

${ }^{h}$ MSCs + mitogenic/allogenic stimulated T cells. T cell activation and proliferation assays. Subset analysis for CD4+ and CD8+ T cells. PCR for COX1 and COX2. ELISA for PGE2

MSCs $+T$ cells. MSCs were primed with IFN- $\alpha$, IFN- $\gamma$, TNF- $\alpha$, or IL-1 $\beta$ or unstimulated. T cell proliferation assay. Flow cytometry to assess Iymphocyte activation. ELISA for IFN- $\gamma$, IL-8, and CCL5. T cell migration assay.

'MSC + PBMCs stimulated with PHA or MLR; MSC primed with IFN- $\gamma$ or TNF- $\alpha$ : immunogenicity and T cell proliferation; PBMC cytokine profiles, activation markers, and immunesuppressive factors (IDO, PGE2, HGF, CIITA).

MSCs + PBMCs: MLR or mitogen-induced T cell proliferation, time- and dose-dependent suppression, dependent on soluble mediators (but most probably not TGF- $\beta$, HGF, and

IL-10).

${ }^{k}$ MSCs + PBMCs: PBMC proliferation assay. PCR for IDO, TGF- $\beta$, and CXCL-10. Application of PBMCs and MSCs in an in vivo mouse allograft rejection model.

'MSCs and CD8+ $T$ cells: induction of HLA-specific alloreactivity by MSC-educated CD8 ${ }^{+} T C$.

${ }^{m}$ MSCs stimulated with IFN- $\gamma$ and MSCs + T cells. ELISA for IL-2, IL-10, and TGF- $\beta 1$. Electrophoresis for IDO.

"MSCs + PHA stimulated T cells. Effects on T cell proliferation, MLR assay, T cell cycle, T cell apoptosis, early activation, and T cell subsets were assessed. ${ }^{\circ} \mathrm{MSC}+$ PHA-stimulated T cells: cytokines: IL-12, IL-15, and PDGF-AA.

AT, adipose tissue; BM, bone marrow; MLR, mixed lymphocyte reaction; MSC, mesenchymal stromal cells; PBMC, peripheral blood mononuclear cells; PL, placenta; Treg, regulatory T cells; CTL, cytotoxic T lymphocytes; DC, dendritic cells UC, umbilical cord; UCB, umbilical cord blood; WJ, Wharton's jelly. 
inflammatory conditions, such as allergic airway inflammation (52). In an inflammatory environment, high levels of IFN- $\gamma$ and/ or tumor necrosis factor (TNF)- $\alpha$ increase the expression of TGF$\beta$ by MSCs $(53,54)$, which in turn prompts Th1 cells to express immunosuppressive IL-10 and ultimately reduces their IFN- $\gamma$ production. Furthermore, MSC mediate a downregulation of the Th1 cells IFN- $\gamma$ receptor, which renders them less susceptible to IFN- $\gamma$ (55). In a recent study, MSCs-induced and expanded a subpopulation of T-bet ${ }^{+}$Th1 cells co-expressing IFN- $\gamma$ and IL-10 (55). T-bet is a Th1 cell-specific transcription factor (56). This suggests that the influence of MSCs on IFN- $\gamma$ expression is dependent on several factors, such as the cytokine milieu, the stimulation methods or the types of cells present, showing that we are far from having a full grasp of the effects of MSCs on immune cells.

\section{Comparison}

AT-MSCs and BM-MSCs showed similar results in inhibiting Th1 differentiation, as both significantly reduced the levels of IL-2 and IFN- $\boldsymbol{\gamma}$ (12). Another study compared several MSC populations from birth-associated tissue (umbilical cord lining, cord blood, placenta, and Wharton's jelly), resulting in cord lining MSCs to emerge as the most potent in dampening Th1 and Th2 responses and reducing release of IFN- $\gamma$ by lymphocytes (39). CastroManrreza et al. compared BM-MSCs, UC-MSCs, and PL-MSCs and identified similar proliferation suppression capacities for BM-MSCs and UC-MSCs, but PL-MSCs showed significantly weaker $\mathrm{CD}^{+} / \mathrm{CD}^{+} \mathrm{T}$ lymphocyte suppression (27). AT-MSCs exerted the strongest inhibition on IFN- $\gamma$ secretion and $\mathrm{T}$ cell proliferation compared to BM-MSCs and WJ-MSCs (34).

\section{Effects on CD4 ${ }^{+}$Th2 Cells}

Th2 cells have several functions in the humoral-mediated immune response, as they host the defense against extracellular parasites, inhibit Th1 cells and DCs via IL-10, stimulate B cells via IL-4 and can induce isotype-switches in B cells (57). MSCs have been shown to enhance anti-inflammatory IL-4 production by Th 2 cells, supposedly via a PGE2 (48). In inflammatory diseases that are associated with high amounts of Th2 cells (e.g., allergies, asthma, Crohn's disease), MSCs were able to ameliorate disease activity by inhibiting the cytokine production of Th2 cells (IL- 4 and IL-5) and increase Th1-derived cytokines (IFN- $\gamma$ and IL-2) $(51,58)$.

\section{Comparison}

There are a small number of studies concentrating on the comparison of various MSC sources on T cell subsets. Xishan et al. compared AT-MSCs and BM-MSCs on their ability to induce Th0 differentiation into Th1 and Th2 cells and could show that both populations had no significant effect on the levels of the Th2associated cytokines IL-4 and IL-10 (12). Concerning Th2 cells, data is especially scarce.

\section{Effects on CD4 ${ }^{+}$Th17 Cells}

Th17 cells play an important role in the human immune system as effectors against extracellular bacterial and fungal infections, but have also been associated with autoimmune diseases, such as multiple sclerosis, psoriasis, rheumatoid arthritis, inflammatory bowel disease, systemic lupus erythematosus, and asthma (59).
Although studies about the effects of MSCs on Th17 cells seem to yield rather consistent results, presenting MSCs as potent inhibitors of Th17-mediated immune responses (60-62), data exists where Th17 cells appear to be stimulated by MSCs in vitro (63). The time at which MSCs are added could be important, as Carrión et al. demonstrated opposing effects of MSCs on Th1 and Th17 cells relative to the state of $\mathrm{CD}^{+} \mathrm{T}$ cell activation (49).

\section{Comparison}

AT-MSCs, UC-MSCs, and BM-MSCs have all proven to be effective in suppressing the Th17 immune response $(41,60,64)$, but studies directly comparing them are rare. In a mouse model of experimental colitis, UC-MSCs and BM-MSCs demonstrated a similar inhibition of Th17 cells, shifting the Th17/Treg ratio toward a more immunosuppressive balance (64).

\section{Effects on CD4 ${ }^{+}$FoxP3+ Regulatory $\mathrm{T}$ Cells (Tregs)}

Regulatory $\mathrm{T}$ cells are either derived in the thymus as mature Tregs, or from $\mathrm{CD} 4{ }^{+} \mathrm{CD} 25^{-}$naïve $\mathrm{T}$ cells as peripherally derived Tregs under the influence of TGF- $\beta$ and IL-2 (65). Tregs target effector T cells and DCs $(65,66)$ by inhibiting their differentiation, function, and maturation to prevent autoimmunity and establish a peripheral tolerance (67). MSCs have been shown to induce Tregs via a multitude of factors. HLA-G5, a non-classical HLA class I molecule, plays an important role in the induction of Tregs (68). Another factor of MSCs involved in the activation of Tregs is TGF- $\beta$, which seems to be constitutively expressed by MSCs (69). Additionally, MSCs were reported to elevate IL-10 production by Tregs and DCs $(70,71)$, whereby DC-derived IL-10 in turn promotes the expansion of Tregs (72). Tregs can also be indirectly activated by MSCs through an upregulation of Fas ligand (FasL)/Fas-mediated death pathway, which targets $\mathrm{T}$ cells via cell-cell contact and leads to increased apoptosis and Treg induction (73). In several in vivo settings, MSCs increased Tregs, thereby ameliorating disease states as well as promoting graft survival in transplant experiments $(41,50,74-76)$.

\section{Comparison}

In an in vitro study that compared BM-MSCs and UC-MSCs on their ability to induce Tregs, UC-MSCs had a significantly greater potential to induce Tregs than BM-MSCs (26). Chao et al., on the other hand, did not report a difference in Treg induction of BM-MSCs and UC-MSCs in an in vivo experiment (77).

\section{Effects on CD8 ${ }^{+}$T Cells (CTL)}

Cytotoxic Tlymphocytes (CTLs) are major effectors in the immune system through targeting virus-infected cells as well as tumor cells. CTLs have a crucial role in autoimmunity and transplant rejection. CTL activation is triggered following the interaction of the T cell receptor (TCR) with the specific allogeneic peptideHLA-I complex. The activation of lymphocytes can be divided into several steps, which all have a corresponding phenotype: $\mathrm{CD}^{-} 9^{-} \mathrm{CD} 25^{-} \mathrm{HLA}^{-D R^{-}}$(non-activated), CD69 ${ }^{+} \mathrm{CD}^{-} 5^{-} \mathrm{HLA}^{-} \mathrm{DR}^{-}$ (earlier activated), $\mathrm{CD}^{2} 9^{+} \mathrm{CD} 25^{+} \mathrm{HLA}-\mathrm{DR}^{-}$(intermediate activated) and $\mathrm{CD}^{6} 9^{+} \mathrm{CD} 25^{+} \mathrm{HLA}-\mathrm{DR}^{+}$(later activated). It was 
reported that MSCs are able to dampen the immune response of CTLs as well as inhibiting their proliferation and maturation $(36,37,51)$. MSC downregulate the CD8 surface marker on CTLs via an indirect pathway involving $\mathrm{CD} 14^{+}$monocytes, requiring cell-cell contact between the monocytes and the CTLs (78). In this process, CD28 is downregulated on CTLs indicating loss of effector-type and gain of regulatory functions (78).

\section{Comparison}

Ribeiro et al. investigated AT-MSCs, BM-MSCs, and UC-MSCs as to their effect of inhibiting $\mathrm{CD} 4^{+} / \mathrm{CD}^{+}$lymphocyte activation (36). Co-culture with BM-MSCs and UC-MSCs similarly inhibited lymphocyte activation, whereas the majority of the $\mathrm{CD} 8^{+}$cells were of the earlier activated phenotype. AT-MSCs here emerged as the most immunosuppressive population, as the majority of the T Cells were found to be in the non-activated compartment (36). Different effects on $\mathrm{CD}^{+}$mediated alloreactivity are reported by Roemeling-van Rhijn et al., addressing the capacity of AT- versus BM-MSC to induce HLA-specific alloreactivity (38). CD8 ${ }^{+} \mathrm{T}$ cells educated with IFN- $\gamma$-treated AT-MSC evoked $31 \%$ specific lysis of AT-MSCs with identical HLA. IFN- $\gamma$-treated BM-MSC, however, resulted in 76\% HLA-specific killing of HLA-identical BM-MSC.

\section{EFFECTS ON MONOCYTES, MACROPHAGES, AND DENDRITIC CELLS}

Monocytes are a subpopulation of leukocytes able to differentiate into macrophages and DCs. Macrophages and DCs are antigenpresenting cells that can initiate an immune response and act as a mediator between the innate and the adaptive immune system. MSCs were reported to strongly induce the secretion of IL-10 on $\mathrm{CD} 14^{+}$monocytes via HGF, thereby suppressing $\mathrm{T}$ cell proliferation (79). Melief et al. could show that MSCs promote the survival of monocytes and induce the differentiation into $\mathrm{CD} 163^{+} \mathrm{CD} 206^{+}$ type 2 macrophages, which secrete IL-10 and CCL18 (69). CCL18 in turn has a crucial role in inducing Tregs (69). MSCs were frequently shown to be able to inhibit the proinflammatory functions of DCs and macrophages and skew the cells toward a more immunosuppressive response $(70,71,80)$. The proinflammatory molecules TNF- $\alpha$ and macrophage inflammatory protein (MIP)$1 \beta$, produced by macrophages and mature DCs, were suppressed under the influence of MSCs (80). Concerning maturation markers such as CD1a, CD14, CD83 and HLA-DR, MSCs inhibited the maturation of DCs and furthermore downregulated the costimulatory molecules CD86/CD80 (81, 82). Conflicting data exist, as Laranjera et al. could not detect any influence of MSCs on maturation markers CD83, CCR7, and HLA-DR (80) on DCs, thus leading the group to suppose that MSCs exhibit their anti-inflammatory functions on macrophages and DCs mainly by inhibiting the secretion of proinflammatory cytokines. MSCs are also able to inhibit the differentiation at a more upstream step by interfering with monocyte maturation (83).

\section{Comparison}

AT-MSCs seem to have a more pronounced effect on DC differentiation than BM-MSCs (28). Saeidi et al. examined UC-MSCs on their potential to interfere with maturation and endocytotic capability of DCs comparing them with BM-MSCs (81). While being equally effective in hampering the maturation of DCs, UC-MSCs had a stronger effect on reducing the endocytotic ability of DCs (81). Jin et al. compared anti-inflammatory activity of BM-, AT-, and UCB-MSCs (29). UCB-MSCs were most potent in suppressing cytokine release from LPS-challenged alveolar macrophages. Angiopoietin-1 was at least partly responsible for this effect.

\section{CONCLUSION}

The increasing numbers of studies conducted on comparing MSC sources in vitro and in vivo yield largely congruent results, presenting MSCs as promising cells for a multitude of immunological applications (Table 1). Nevertheless, the heterogeneity in MSC populations and experimental protocols still poses a major obstacle when trying to compare and merge different results and to translate them into clinical practice (84). Our survey reflects that the vast majority of data showed no significant deficiencies in the immunomodulatory potential of MSCs from alternative sources but often even stronger immunosuppressive capabilities than BM-MSCs $(26,28,30,33,34$, $36,81)$. This was especially the case for MSCs from adipose tissue $(28,32-34,36)$. This claim, however, is based on the few studies directly comparing MSCs from different tissue sources. Future studies should elucidate whether the similarities of tissue MSCs in vitro relate to similar functions in situ or are artificially gained by ex vivo isolation and culture adaptation $(85,86)$ and whether the subtle differences in function relate to the role of MSCs in situ. What is certain is that MSCs expanded in vitro are highly sensitive to their microenvironment; they may alternate their function based on the surrounding conditions. Important parameters are the culture conditions (e.g., choice of serum supplement), types of immune cells present, cell activation status, ratio of MSC to immune cells and, of course, the cytokine levels in the milieu (87-90). Additionally, variations in isolation methods, culture media, cell counts, and different stimulation protocols can further blur the potential differences among distinct MSC sources. A standardization of assays to assess the effects of MSCs is essential to guarantee trustworthy and reproducible results (18). Ideally, these assays are capable of predicting efficacy of MSCs in vivo, to serve as potency assay. We would therefore appreciate more comparative studies to give us a better understanding of the immunomodulatory mechanisms of MSCs, facilitating the choice between different sources for defined clinical settings to improve safety and efficacy of MSC-based therapies.

\section{AUTHOR CONTRIBUTIONS}

PM, KB: conception, acquisition, analysis, or interpretation of data, drafting and critical revision, final approval before submission, and agreement to be accountable for all aspects of the work in ensuring that questions related to the accuracy or integrity of any part of the work are appropriately investigated and resolved. 


\section{ACKNOWLEDGMENTS}

We would like to thank Stefanie Uhlig, Susanne Elvers-Hornung and Andrea Hecker for excellent technical and scientific support and Eva Ossenbühn for critical proofreading.

\section{REFERENCES}

1. Sharma RR, Pollock K, Hubel A, McKenna D. Mesenchymal stem or stromal cells: a review of clinical applications and manufacturing practices. Transfusion (2014) 54(5):1418-37. doi:10.1111/trf.12421

2. Wang Y, Chen X, Cao W, Shi Y. Plasticity of mesenchymal stem cells in immunomodulation: pathological and therapeutic implications. Nat Immunol (2014) 15(11):1009-16. doi:10.1038/ni.3002

3. Friedenstein AJ, Gorskaja JF, Kulagina NN. Fibroblast precursors in normal and irradiated mouse hematopoietic organs. Exp Hematol (1976) 4(5):267-74.

4. de Girolamo L, Lucarelli E, Alessandri G, Avanzini MA, Bernardo ME, Biagi E, et al. Mesenchymal stem/stromal cells: a new "cells as drugs" paradigm. Efficacy and critical aspects in cell therapy. Curr Pharm Des (2013) 19(13):2459-73. do i:10.2174/1381612811319130015

5. Kern S, Eichler H, Stoeve J, Kluter H, Bieback K. Comparative analysis of mesenchymal stem cells from bone marrow, umbilical cord blood, or adipose tissue. Stem Cells (2006) 24(5):1294-301. doi:10.1634/stemcells.2005-0342

6. Bieback K, Brinkmann I. Mesenchymal stromal cells from human perinatal tissues: from biology to cell therapy. World J Stem Cells (2010) 2(4):81-92. doi:10.4252/wjsc.v2.i4.81

7. Hass R, Kasper C, Bohm S, Jacobs R. Different populations and sources of human mesenchymal stem cells (MSC): a comparison of adult and neonatal tissue-derived MSC. Cell Commun Signal (2011) 9:12. doi:10.1186/1478-811X-9-12

8. Bieback K, Kern S, Kluter H, Eichler H. Critical parameters for the isolation of mesenchymal stem cells from umbilical cord blood. Stem Cells (2004) 22(4):625-34. doi:10.1634/stemcells.22-4-625

9. Barlow S, Brooke G, Chatterjee K, Price G, Pelekanos R, Rossetti T, et al. Comparison of human placenta- and bone marrow-derived multipotent mesenchymal stem cells. Stem Cells Dev (2008) 17(6):1095-107. doi:10.1089/ scd.2007.0154

10. In 't Anker PS, Scherjon SA, Kleijburg-van der Keur C, de Groot-Swings GM, Claas FH, Fibbe WE, et al. Isolation of mesenchymal stem cells of fetal or maternal origin from human placenta. Stem Cells (2004) 22(7):1338-45. doi:10.1634/stemcells.2004-0058

11. Hoogduijn MJ, Betjes MG, Baan CC. Mesenchymal stromal cells for organ transplantation: different sources and unique characteristics? Curr Opin Organ Transplant (2014) 19(1):41-6. doi:10.1097/MOT.0000000000000036

12. Xishan Z, Baoxin H, Xinna Z, Jun R. Comparison of the effects of human adipose and bone marrow mesenchymal stem cells on $\mathrm{T}$ lymphocytes. Cell Biol Int (2013) 37(1):11-8. doi:10.1002/cbin.10002

13. Yang ZX, Han ZB, Ji YR, Wang YW, Liang L, Chi Y, et al. CD106 identifies a subpopulation of mesenchymal stem cells with unique immunomodulatory properties. PLoS One (2013) 8(3):e59354. doi:10.1371/journal. pone.0059354

14. Maumus M, Peyrafitte JA, D’Angelo R, Fournier-Wirth C, Bouloumie A, Casteilla L, et al. Native human adipose stromal cells: localization, morphology and phenotype. Int J Obes (2011) 35(9):1141-53. doi:10.1038/ijo.2010.269

15. Bourin P, Bunnell BA, Casteilla L, Dominici M, Katz AJ, March KL, et al. Stromal cells from the adipose tissue-derived stromal vascular fraction and culture expanded adipose tissue-derived stromal/stem cells: a joint statement of the International Federation for Adipose Therapeutics and Science (IFATS) and the International Society for Cellular Therapy (ISCT). Cytotherapy (2013) 15(6):641-8. doi:10.1016/j.jcyt.2013.02.006

16. Karagianni M, Brinkmann I, Kinzebach S, Grassl M, Weiss C, Bugert P, et al. A comparative analysis of the adipogenic potential in human mesenchymal stromal cells from cord blood and other sources. Cytotherapy (2013) 15(1):76-88. doi:10.1016/j.jcyt.2012.11.001

17. Reinisch A, Etchart N, Thomas D, Hofmann NA, Fruehwirth M, Sinha S, et al. Epigenetic and in vivo comparison of diverse MSC sources reveals an endochondral signature for human hematopoietic niche formation. Blood (2015) 125(2):249-60. doi:10.1182/blood-2014-04-572255

\section{FUNDING}

This work was supported by research funds of the German Federal Ministry of Education and Research (START-MSC: 01GN0531 and 01GN0939).

18. Krampera M, Galipeau J, Shi Y, Tarte K, Sensebe L; MSC Committee of the International Society for Cellular Therapy (ISCT). Immunological characterization of multipotent mesenchymal stromal cells - the International Society for Cellular Therapy (ISCT) working proposal. Cytotherapy (2013) 15(9):1054-61. doi:10.1016/j.jcyt.2013.02.010

19. Rasmusson I, Ringden O, Sundberg B, Le Blanc K. Mesenchymal stem cells inhibit lymphocyte proliferation by mitogens and alloantigens by different mechanisms. Exp Cell Res (2005) 305(1):33-41. doi:10.1016/j. yexcr.2004.12.013

20. Nauta AJ, Westerhuis G, Kruisselbrink AB, Lurvink EG, Willemze R, Fibbe WE. Donor-derived mesenchymal stem cells are immunogenic in an allogeneic host and stimulate donor graft rejection in a nonmyeloablative setting. Blood (2006) 108(6):2114-20. doi:10.1182/blood-2005-11-011650

21. Ankrum JA, Ong JF, Karp JM. Mesenchymal stem cells: immune evasive, not immune privileged. Nat Biotechnol (2014) 32(3):252-60. doi:10.1038/nbt.2816

22. Prasanna SJ, Gopalakrishnan D, Shankar SR, Vasandan AB. Pro-inflammatory cytokines, IFNgamma and TNFalpha, influence immune properties of human bone marrow and Wharton jelly mesenchymal stem cells differentially. PLoS One (2010) 5(2):e9016. doi:10.1371/journal.pone.0009016

23. Duffy MM, Ritter T, Ceredig R, Griffin MD. Mesenchymal stem cell effects on T-cell effector pathways. Stem Cell Res Ther (2011) 2(4):34. doi:10.1186/scrt75

24. Tsai MS, Hwang SM, Chen KD, Lee YS, Hsu LW, Chang YJ, et al. Functional network analysis of the transcriptomes of mesenchymal stem cells derived from amniotic fluid, amniotic membrane, cord blood, and bone marrow. Stem Cells (2007) 25(10):2511-23. doi:10.1634/stemcells.2007-0023

25. Baglio SR, Rooijers K, Koppers-Lalic D, Verweij FJ, Perez Lanzon M, Zini $\mathrm{N}$, et al. Human bone marrow- and adipose-mesenchymal stem cells secrete exosomes enriched in distinctive miRNA and tRNA species. Stem Cell Res Ther (2015) 6(1):127. doi:10.1186/s13287-015-0116-Z

26. Barcia RN, Santos JM, Filipe M, Teixeira M, Martins JP, Almeida J, et al. What makes umbilical cord tissue-derived mesenchymal Stromal cells superior immunomodulators when compared to bone marrow derived mesenchymal stromal cells? Stem Cells Int (2015) 2015:583984. doi:10.1155/2015/583984

27. Castro-Manrreza ME, Mayani H, Monroy-Garcia A, Flores-Figueroa E, Chavez-Rueda K, Legorreta-Haquet V, et al. Human mesenchymal stromal cells from adult and neonatal sources: a comparative in vitro analysis of their immunosuppressive properties against T cells. Stem Cells Dev (2014) 23(11):1217-32. doi:10.1089/scd.2013.0363

28. Ivanova-Todorova E, Bochev I, Mourdjeva M, Dimitrov R, Bukarev D, Kyurkchiev S, et al. Adipose tissue-derived mesenchymal stem cells are more potent suppressors of dendritic cells differentiation compared to bone marrow-derived mesenchymal stem cells. Immunol Lett (2009) 126(1-2):37-42. doi:10.1016/j.imlet.2009.07.010

29. Jin HJ, Bae YK, Kim M, Kwon SJ, Jeon HB, Choi SJ, et al. Comparative analysis of human mesenchymal stem cells from bone marrow, adipose tissue, and umbilical cord blood as sources of cell therapy. Int J Mol Sci (2013) 14(9):17986-8001. doi:10.3390/ijms140917986

30. Li X, Bai J, Ji X, Li R, Xuan Y, Wang Y. Comprehensive characterization of four different populations of human mesenchymal stem cells as regards their immune properties, proliferation and differentiation. Int J Mol Med (2014) 34(3):695-704. doi:10.3892/ijmm.2014.1821

31. Luan X, Li G, Wang G, Wang F, Lin Y. Human placenta-derived mesenchymal stem cells suppress $\mathrm{T}$ cell proliferation and support the culture expansion of cord blood CD34(+) cells: a comparison with human bone marrow-derived mesenchymal stem cells. Tissue Cell (2013) 45(1):32-8. doi:10.1016/j. tice.2012.09.002

32. Montespan F, Deschaseaux F, Sensebe L, Carosella ED, Rouas-Freiss N. Osteodifferentiated mesenchymal stem cells from bone marrow and adipose tissue express HLA-G and display immunomodulatory properties in HLAmismatched settings: implications in bone repair therapy. J Immunol Res (2014) 2014:230346. doi:10.1155/2014/230346 
33. Najar M, Raicevic G, Boufker HI, Fayyad Kazan H, De Bruyn C, Meuleman $\mathrm{N}$, et al. Mesenchymal stromal cells use PGE2 to modulate activation and proliferation of lymphocyte subsets: combined comparison of adipose tissue, Wharton's jelly and bone marrow sources. Cell Immunol (2010) 264(2):171-9. doi:10.1016/j.cellimm.2010.06.006

34. Najar M, Raicevic G, Fayyad-Kazan H, De Bruyn C, Bron D, Toungouz M, et al. Impact of different mesenchymal stromal cell types on T-cell activation, proliferation and migration. Int Immunopharmacol (2013) 15(4):693-702. doi:10.1016/j.intimp.2013.02.020

35. Puissant B, Barreau C, Bourin P, Clavel C, Corre J, Bousquet C, et al. Immunomodulatory effect of human adipose tissue-derived adult stem cells: comparison with bone marrow mesenchymal stem cells. Br J Haematol (2005) 129(1):118-29. doi:10.1111/j.1365-2141.2005.05409.x

36. Ribeiro A, Laranjeira P, Mendes S, Velada I, Leite C, Andrade P, et al. Mesenchymal stem cells from umbilical cord matrix, adipose tissue and bone marrow exhibit different capability to suppress peripheral blood B, natural killer and T cells. Stem Cell Res Ther (2013) 4(5):125. doi:10.1186/scrt336

37. Roemeling-van Rhijn M, Khairoun M, Korevaar SS, Lievers E, Leuning DG, Ijzermans JN, et al. Human bone marrow- and adipose tissue-derived mesenchymal stromal cells are immunosuppressive and in a humanized allograft rejection model. J Stem Cell Res Ther (2013) 6(Suppl 1):20780. doi:10.4172/2157-7633.S6-001

38. Roemeling-van Rhijn M, Reinders ME, Franquesa M, Engela AU, Korevaar SS, Roelofs $\mathrm{H}$, et al. Human allogeneic bone marrow and adipose tissue derived mesenchymal stromal cells induce CD8+ cytotoxic T cell reactivity. J Stem Cell Res Ther (2013) 3(Suppl 6):004. doi:10.4172/2157-7633.S6-004

39. Stubbendorff M, Deuse T, Hua X, Phan TT, Bieback K, Atkinson K, et al. Immunological properties of extraembryonic human mesenchymal stromal cells derived from gestational tissue. Stem Cells Dev (2013) 22(19):2619-29. doi: $10.1089 / \mathrm{scd} .2013 .0043$

40. Yoo KH, Jang IK, Lee MW, Kim HE, Yang MS, Eom Y, et al. Comparison of immunomodulatory properties of mesenchymal stem cells derived from adult human tissues. Cell Immunol (2009) 259(2):150-6. doi:10.1016/j. cellimm.2009.06.010

41. Larocca RA, Moraes-Vieira PM, Bassi EJ, Semedo P, de Almeida DC, da Silva $\mathrm{MB}$, et al. Adipose tissue-derived mesenchymal stem cells increase skin allograft survival and inhibit Th-17 immune response. PLoS One (2013) 8(10):e76396. doi:10.1371/journal.pone.0076396

42. Jacobs SA, Roobrouck VD, Verfaillie CM, Van Gool SW. Immunological characteristics of human mesenchymal stem cells and multipotent adult progenitor cells. Immunol Cell Biol (2013) 91(1):32-9. doi:10.1038/icb.2012.64

43. Glennie S, Soeiro I, Dyson PJ, Lam EW, Dazzi F. Bone marrow mesenchymal stem cells induce division arrest anergy of activated T cells. Blood (2005) 105(7):2821-7. doi:10.1182/blood-2004-09-3696

44. Fierabracci A, Del Fattore A, Luciano R, Muraca M, Teti A, Muraca M. Recent advances in mesenchymal stem cell immunomodulation: the role of microvesicles. Cell Transplant (2015) 24(2):133-49. doi:10.3727/096368913X675728

45. Di Nicola M, Carlo-Stella C, Magni M, Milanesi M, Longoni PD, Matteucci $\mathrm{P}$, et al. Human bone marrow stromal cells suppress T-lymphocyte proliferation induced by cellular or nonspecific mitogenic stimuli. Blood (2002) 99(10):3838-43. doi:10.1182/blood.V99.10.3838

46. Meisel R, Zibert A, Laryea M, Gobel U, Daubener W, Dilloo D. Human bone marrow stromal cells inhibit allogeneic T-cell responses by indoleamine 2,3-dioxygenase-mediated tryptophan degradation. Blood (2004) 103(12):4619-21. doi:10.1182/blood-2003-11-3909

47. Wang Q, Yang Q, Wang Z, Tong H, Ma L, Zhang Y, et al. Comparative analysis of human mesenchymal stem cells from fetal-bone marrow, adipose tissue, and Warton's jelly as sources of cell immunomodulatory therapy. Hum Vaccin Immunother (2015). doi:10.1080/21645515.2015.1030549

48. Aggarwal S, Pittenger MF. Human mesenchymal stem cells modulate allogeneic immune cell responses. Blood (2005) 105(4):1815-22. doi:10.1182/ blood-2004-04-1559

49. Carrion F, Nova E, Luz P, Apablaza F, Figueroa F. Opposing effect of mesenchymal stem cells on Th1 and Th17 cell polarization according to the state of CD4+ T cell activation. Immunol Lett (2011) 135(1-2):10-6. doi:10.1016/j. imlet.2010.09.006

50. Sun L, Akiyama K, Zhang H, Yamaza T, Hou Y, Zhao S, et al. Mesenchymal stem cell transplantation reverses multiorgan dysfunction in systemic lupus erythematosus mice and humans. Stem Cells (2009) 27(6):1421-32. doi:10.1002/stem.68

51. Cho KS, Kim YW, Kang MJ, Park HY, Hong SL, Roh HJ. Immunomodulatory effect of mesenchymal stem cells on T lymphocyte and cytokine expression in nasal polyps. Otolaryngol Head Neck Surg (2014) 150(6):1062-70. doi:10.1177/0194599814525751

52. Kang B-J, Ryu H-H, Park SS, Koyama Y, Kikuchi M, Woo H-M, et al. Comparing the osteogenic potential of canine mesenchymal stem cells derived from adipose tissues, bone marrow, umbilical cord blood, and Wharton's jelly for treating bone defects. J Vet Sci (2012) 13(3):299. doi:10.4142/jvs.2012.13.3.299

53. English K, Ryan JM, Tobin L, Murphy MJ, Barry FP, Mahon BP. Cell contact, prostaglandin $\mathrm{E}(2)$ and transforming growth factor beta 1 play non-redundant roles in human mesenchymal stem cell induction of CD4+CD25(High) forkhead box P3+ regulatory T cells. Clin Exp Immunol (2009) 156(1):149-60. doi:10.1111/j.1365-2249.2009.03874.x

54. Engela AU, Baan CC, Dor FJ, Weimar W, Hoogduijn MJ. On the interactions between mesenchymal stem cells and regulatory $\mathrm{T}$ cells for immunomodulation in transplantation. Front Immunol (2012) 3:126. doi:10.3389/ fimmu.2012.00126

55. Selleri S, Dieng MM, Nicoletti S, Louis I, Beausejour C, Le Deist F, et al. Cord-blood-derived mesenchymal stromal cells downmodulate CD4+ T-cell activation by inducing IL-10-producing Th1 cells. Stem Cells Dev (2013) 22(7):1063-75. doi:10.1089/scd.2012.0315

56. Szabo SJ, Kim ST, Costa GL, Zhang X, Fathman CG, Glimcher LH. A novel transcription factor, T-bet, directs Th1 lineage commitment. Cell (2000) 100(6):655-69. doi:10.1016/S0092-8674(00)80702-3

57. Batten P, Sarathchandra P, Antoniw JW, Tay SS, Lowdell MW, Taylor PM, et al. Human mesenchymal stem cells induce $\mathrm{T}$ cell anergy and downregulate $\mathrm{T}$ cell allo-responses via the $\mathrm{TH} 2$ pathway: relevance to tissue engineering human heart valves. Tissue Eng (2006) 12(8):2263-73. doi:10.1089/ ten.2006.12.2263

58. Algeri M, Conforti A, Pitisci A, Starc N, Tomao L, Bernardo ME, et al. Mesenchymal stromal cells and chronic inflammatory bowel disease. Immunol Lett (2015). doi:10.1016/j.imlet.2015.06.018

59. Singh RP, Hasan S, Sharma S, Nagra S, Yamaguchi DT, Wong DT, et al. Th17 cells in inflammation and autoimmunity. Autoimmun Rev (2014) 13(12):1174-81. doi:10.1016/j.autrev.2014.08.019

60. Lee JJ, Jeong HJ, Kim MK, Wee WR, Lee WW, Kim SU, et al. CD39-mediated effect of human bone marrow-derived mesenchymal stem cells on the human Th17 cell function. Purinergic Signal (2014) 10(2):357-65. doi:10.1007/ s11302-013-9385-0

61. Tatara R, Ozaki K, Kikuchi Y, Hatanaka K, Oh I, Meguro A, et al. Mesenchymal stromal cells inhibit Th17 but not regulatory T-cell differentiation. Cytotherapy (2011) 13(6):686-94. doi:10.3109/14653249.2010.542456

62. Qu X, Liu X, Cheng K, Yang R, Zhao RC. Mesenchymal stem cells inhibit Th17 cell differentiation by IL-10 secretion. Exp Hematol (2012) 40(9):761-70. doi:10.1016/j.exphem.2012.05.006

63. Eljaafari A, Tartelin ML, Aissaoui H, Chevrel G, Osta B, Lavocat F, et al. Bone marrow-derived and synovium-derived mesenchymal cells promote Th17 cell expansion and activation through caspase 1 activation: contribution to the chronicity of rheumatoid arthritis. Arthritis Rheum (2012) 64(7):2147-57. doi:10.1002/art.34391

64. Li L, Liu S, Xu Y, Zhang A, Jiang J, Tan W, et al. Human umbilical cord-derived mesenchymal stem cells downregulate inflammatory responses by shifting the Treg/Th17 profile in experimental colitis. Pharmacology (2013) 92(5-6):257-64. doi:10.1159/000354883

65. Josefowicz SZ, Lu LF, Rudensky AY. Regulatory T cells: mechanisms of differentiation and function. Annu Rev Immunol (2012) 30:531-64. doi:10.1146/ annurev.immunol.25.022106.141623

66. Chattopadhyay G, Shevach EM. Antigen-specific induced T regulatory cells impair dendritic cell function via an IL-10/MARCH1-dependent mechanism. J Immunol (2013) 191(12):5875-84. doi:10.4049/jimmunol.1301693

67. Wing K, Sakaguchi S. Regulatory T cells exert checks and balances on self tolerance and autoimmunity. Nat Immunol (2010) 11(1):7-13. doi:10.1038/ ni. 1818

68. Selmani Z, Naji A, Zidi I, Favier B, Gaiffe E, Obert L, et al. Human leukocyte antigen-G5 secretion by human mesenchymal stem cells is required to suppress $\mathrm{T}$ lymphocyte and natural killer function and to induce 
CD4+CD25highFOXP3+ regulatory T cells. Stem Cells (2008) 26(1):212-22. doi:10.1634/stemcells.2007-0554

69. Melief SM, Schrama E, Brugman MH, Tiemessen MM, Hoogduijn MJ, Fibbe WE, et al. Multipotent stromal cells induce human regulatory T cells through a novel pathway involving skewing of monocytes toward anti-inflammatory macrophages. Stem Cells (2013) 31(9):1980-91. doi:10.1002/stem.1432

70. Nemeth K, Leelahavanichkul A, Yuen PS, Mayer B, Parmelee A, Doi K, et al. Bone marrow stromal cells attenuate sepsis via prostaglandin $\mathrm{E}(2)$-dependent reprogramming of host macrophages to increase their interleukin-10 production. Nat Med (2009) 15(1):42-9. doi:10.1038/nm.1905

71. Zhang W, Ge W, Li C, You S, Liao L, Han Q, et al. Effects of mesenchymal stem cells on differentiation, maturation, and function of human monocyte-derived dendritic cells. Stem Cells Dev (2004) 13(3):263-71. doi:10.1089/154732804323099190

72. Maccario R, Podesta M, Moretta A, Cometa A, Comoli P, Montagna D, et al. Interaction of human mesenchymal stem cells with cells involved in alloantigen-specific immune response favors the differentiation of CD4+ T-cell subsets expressing a regulatory/suppressive phenotype. Haematologica (2005) 90(4):516-25.

73. Wang L, Zhao Y, Shi S. Interplay between mesenchymal stem cells and lymphocytes: implications for immunotherapy and tissue regeneration. J Dent Res (2012) 91(11):1003-10. doi:10.1177/0022034512460404

74. Casiraghi F, Azzollini N, Cassis P, Imberti B, Morigi M, Cugini D, et al. Pretransplant infusion of mesenchymal stem cells prolongs the survival of a semiallogeneic heart transplant through the generation of regulatory $\mathrm{T}$ cells. J Immunol (2008) 181(6):3933-46. doi:10.4049/jimmunol.181.6.3933

75. Fan XB, Gay FPH, Ong SY, Ang JML, Chu PPY, Bari S, et al. Mesenchymal stromal cell supported umbilical cord blood ex vivo expansion enhances regulatory T cells and reduces graft versus host disease. Cytotherapy (2013) 15(5):610-9. doi:10.1016/j.jcyt.2012.12.007

76. Tasso R, Ilengo C, Quarto R, Cancedda R, Caspi RR, Pennesi G. Mesenchymal stem cells induce functionally active T-regulatory lymphocytes in a paracrine fashion and ameliorate experimental autoimmune uveitis. Invest Ophthalmol Vis Sci (2012) 53(2):786-93. doi:10.1167/iovs.11-8211

77. Chao YH, Wu HP, Wu KH, Tsai YG, Peng CT, Lin KC, et al. An increase in $\mathrm{CD} 3+\mathrm{CD} 4+\mathrm{CD} 25+$ regulatory $\mathrm{T}$ cells after administration of umbilical cord-derived mesenchymal stem cells during sepsis. PLoS One (2014) 9(10):e110338. doi:10.1371/journal.pone.0110338

78. Hof-Nahor I, Leshansky L, Shivtiel S, Eldor L, Aberdam D, Itskovitz-Eldor J, et al. Human mesenchymal stem cells shift CD8+ T cells towards a suppressive phenotype by inducing tolerogenic monocytes. J Cell Sci (2012) 125(Pt 19):4640-50. doi:10.1242/jcs.108860

79. Chen PM, Liu KJ, Hsu PJ, Wei CF, Bai CH, Ho LJ, et al. Induction of immunomodulatory monocytes by human mesenchymal stem cell-derived hepatocyte growth factor through ERK1/2. J Leukoc Biol (2014) 96(2):295-303. doi:10.1189/jlb.3A0513-242R

80. Laranjeira P, Gomes J, Pedreiro S, Pedrosa M, Martinho A, Antunes B, et al. Human bone marrow-derived mesenchymal stromal cells differentially inhibit cytokine production by peripheral blood monocytes subpopulations and myeloid dendritic cells. Stem Cells Int (2015) 2015:819084. doi:10.1155/2015/819084
81. Saeidi M, Masoud A, Shakiba Y, Hadjati J, Mohyeddin Bonab M, Nicknam $\mathrm{MH}$, et al. Immunomodulatory effects of human umbilical cord Wharton's jelly-derived mesenchymal stem cells on differentiation, maturation and endocytosis of monocyte-derived dendritic cells. Iran J Allergy Asthma Immunol (2013) 12(1):37-49.

82. Jiang XX, Zhang Y, Liu B, Zhang SX, Wu Y, Yu XD, et al. Human mesenchymal stem cells inhibit differentiation and function of monocyte-derived dendritic cells. Blood (2005) 105(10):4120-6. doi:10.1182/ blood-2004-02-0586

83. Du Rocher B, Mencalha AL, Gomes BE, Abdelhay E. Mesenchymal stromal cells impair the differentiation of CD14(++) CD16(-) CD64(+) classical monocytes into $\mathrm{CD} 14(++) \mathrm{CD} 16(+) \mathrm{CD} 64(++)$ activate monocytes. Cytotherapy (2012) 14(1):12-25. doi:10.3109/14653249.2011.594792

84. Kim N, Cho SG. New strategies for overcoming limitations of mesenchymal stem cell-based immune modulation. Int J Stem Cells (2015) 8(1):54-68. doi:10.15283/ijsc.2015.8.1.54

85. Galderisi U, Giordano A. The gap between the physiological and therapeutic roles of mesenchymal stem cells. Med Res Rev (2014) 34(5):1100-26. doi:10.1002/med.21322

86. Shi C. Recent progress toward understanding the physiological function of bone marrow mesenchymal stem cells. Immunology (2012) 136(2):133-8. doi:10.1111/j.1365-2567.2012.03567.x

87. Kronsteiner B, Wolbank S, Peterbauer A, Hackl C, Redl H, van Griensven M, et al. Human mesenchymal stem cells from adipose tissue and amnion influence T-cells depending on stimulation method and presence of other immune cells. Stem Cells Dev (2011) 20(12):2115-26. doi:10.1089/scd.2011.0031

88. Najar M, Rouas R, Raicevic G, Boufker HI, Lewalle P, Meuleman N, et al. Mesenchymal stromal cells promote or suppress the proliferation of $\mathrm{T}$ lymphocytes from cord blood and peripheral blood: the importance of low cell ratio and role of interleukin-6. Cytotherapy (2009) 11(5):570-83. doi:10.1080/14653240903079377

89. Menard C, Pacelli L, Bassi G, Dulong J, Bifari F, Bezier I, et al. Clinical-grade mesenchymal stromal cells produced under various good manufacturing practice processes differ in their immunomodulatory properties: standardization of immune quality controls. Stem Cells Dev (2013) 22(12):1789-801. doi:10.1089/scd.2012.0594

90. Copland IB, Garcia MA, Waller EK, Roback JD, Galipeau J. The effect of platelet lysate fibrinogen on the functionality of MSCs in immunotherapy. Biomaterials (2013) 34(32):7840-50. doi:10.1016/j. biomaterials.2013.06.050

Conflict of Interest Statement: The authors declare that the work was conducted in the absence of any commercial or financial relationships that could be construed as a potential conflict of interest.

Copyright $\odot 2015$ Mattar and Bieback. This is an open-access article distributed under the terms of the Creative Commons Attribution License (CC BY). The use, distribution or reproduction in other forums is permitted, provided the original author(s) or licensor are credited and that the original publication in this journal is cited, in accordance with accepted academic practice. No use, distribution or reproduction is permitted which does not comply with these terms. 